Fetal Diagnosis and Therapy

\title{
Early Prediction of Hypertensive Disorders of Pregnancy Using Cell-Free Fetal DNA, Cell-Free Total DNA, and Biochemical Markers
}

\author{
Shin Young Kim ${ }^{a}$ Hyun Jin Kim ${ }^{a}$ So Yeon Park ${ }^{a}$ Yoo Jung Han ${ }^{b}$ \\ June Seek Choi ${ }^{b}$ Hyun Mee Ryu a, b \\ a Laboratory of Medical Genetics, Medical Research Institute, Cheil General Hospital and Women's Healthcare \\ Center, and bepartment of Obstetrics and Gynecology, Cheil General Hospital and Women's Healthcare Center, \\ Dankook University College of Medicine, Seoul, Korea
}

\section{Key Words}

Early prediction - Gestational hypertension - Preeclampsia .

Cell-free fetal DNA · Cell-free total DNA · Epigenetic marker ·

Biochemical marker

\begin{abstract}
Objective: To evaluate the predictive value of separate and combined tests using cell-free fetal DNA (cffDNA), cell-free total DNA (cfDNA), and biochemical markers for the early detection of pregnancies with hypertensive disorders. Methods: A nested case-control study was conducted with 135 singleton pregnancies including 17 gestational hypertension cases, 34 preeclampsia (PE) cases, and 84 controls. We performed real-time quantitative PCR to measure levels of DSCR3 and RASSF $1 A$ as cffDNA markers and HYP2 as a cfDNA marker in the first and early second trimesters. Levels of pregnancy-associated plasma protein A (PAPP-A), a-fetoprotein, $\beta$-human chorionic gonadotropin, unconjugated estriol, and inhibin A were also determined. Results: Compared with controls, the median levels and multiples of the median (MoM) values of HYP2 were significantly higher in the PE and hypertensive disorders of pregnancy (HDP) groups at 6-14 and 15-23 weeks. Frist-trimester PAPP-A
\end{abstract}

\section{KARGER}

E-Mail karger@karger.com

www.karger.com/fdt
MoM was significantly lower in PE and HDP than in controls. For $P E$ and HDP, the best model included the first-trimester DSCR3, HYP2, and PAPP-A MoM values achieving detection rates of 67 and $58 \%$ at a fixed $10 \%$ false-positive rate, respectively [area under the receiver operating characteristic curve 0.832 (95\% Cl 0.689-0.928) for PE; 0.751 (0.607-0.863) for HDP]. Discussion: The study demonstrates the potential utility of combined first-trimester cffDNA, cfDNA, and PAPP-A for the early prediction of PE.

(c) 2016 S. Karger AG, Basel

\section{Introduction}

Hypertensive disorders of pregnancy (HDP), which consist of preeclampsia (PE) and gestational hypertension $(\mathrm{GH})$, are the most common complications of pregnancy and are associated with adverse health outcomes for the mother and her offspring. PE, diagnosed by newly elevated blood pressure and proteinuria after 20 weeks of gestation, occurs in about $5-8 \%$ of pregnancies [1-3]. It

S.Y.K. and H.J.K. contributed equally to this work.
(อ) 2016 S. Karger AG, Basel

$1015-3837 / 16 / 0404-0255 \$ 39.50 / 0$
Hyun Mee Ryu, MD, PhD, Department of Obstetrics and Gynecology

Cheil General Hospital and Women's Healthcare Center Dankook University College of Medicine

1-19 Mukjeong-dong, Jung-gu, Seoul 100-380 (Korea)

E-Mail chlorella@empal.com 
is an important cause of perinatal death, preterm birth, and intrauterine growth restriction $[2,4]$. GH is defined as newly elevated blood pressure after 20 weeks of gestation but without proteinuria. $\mathrm{GH}$ occurs in about $6-17 \%$ of pregnancies and is also associated with preterm delivery and infants who are small for their gestational age [1, 3]. Although the precise etiology has yet to be elucidated, the placenta plays a central role in its pathogenesis because of abnormal or inadequate uteroplacental circulation $[5,6]$.

The discovery of placenta-derived cell-free fetal DNA (cffDNA) in maternal blood has opened new avenues in noninvasive prenatal diagnosis [7]. Several studies have found an increase in cffDNA level in maternal plasma in pregnancies complicated by $\mathrm{PE}$ as compared with normal pregnancies [8-11]. cffDNA has been considered as a potential biomarker for predicting $\mathrm{PE}$ in a low-risk population [12]. Originally, cffDNA was determined by quantifying Y chromosome-specific sequences, but these methods depend on the gender and genetic variations of the fetus [8-11]. Therefore, tissue-specific epigenetic DNA methylation differences found between placental trophoblast cells and maternal blood cells are now used to measure cffDNA $[13,14]$. One potential marker is the promoter of the RASSF1A gene, which is reported to be hypermethylated in the placenta and hypomethylated in maternal blood [13, 14]. Recently, Papantoniou et al. [15] reported that increased levels of cffDNA and total cellfree DNA (cfDNA) in maternal plasma can be detected by quantification of RASSF1A at 11-13 weeks of gestation in women who developed PE.

Combinations of first- and second-trimester biochemical markers are highly effective in screening for aneuploidy [16]. Pregnancy-associated plasma protein A (PAPP-A) and $\beta$-human chorionic gonadotropin ( $\beta$ hCG) are used as first-trimester screening, while maternal serum $\alpha$-fetoprotein (AFP), $\beta$-hCG, unconjugated estriol $\left(\mathrm{uE}_{3}\right)$, and inhibin A (InhA) comprise the standard second-trimester screening $[17,18]$. Among these biochemical markers, PAPP-A and InhA levels are associated with subsequent PE [19-22], but their predictive value for PE remains unclear.

The objective of this study was to investigate whether pregnancies with hypertensive disorders, including $\mathrm{GH}$ and PE, can be identified by the amount of cffDNA and cfDNA in maternal plasma using epigenetic markers (DSCR3, RASSF1A, and HYP2) and whether serum levels of biochemical markers (PAPP-A, AFP, $\beta$-hCG, uE 3 , and $(n h A)$ in the first and second trimesters are altered in pregnancies with hypertensive disorders. We also evaluated the predictive values of cffDNA, cfDNA, and biochemical markers, individually and in combination, for the early detection of hypertensive disorders in pregnancy.

\section{Methods}

\section{Study Population}

Ethical approval was obtained from the Institutional Review Board and the Ethics Committee of Cheil General Hospital (No. CGH-IRB-2013-54). All patients provided written informed consent for the collection of samples and subsequent analysis. All women underwent the integrated test for fetal Down syndrome screening. As part of the screening, serum levels of PAPP-A were measured at 11-13 weeks of gestation and serum levels of the quadruple test markers $\mathrm{AFP}, \mathrm{uE}_{3}, \beta$-hCG, and InhA were measured at 15-20 weeks using routine automated analyzers. The values were transformed to multiples of the median (MoM) after adjusting for gestational age and maternal body mass index (BMI).

We performed a nested case-control study of women with singleton pregnancies who received regular antenatal care at the prenatal care unit of the Department of Obstetrics and Gynecology at Cheil General Hospital between August 2010 and August 2014. Maternal blood samples were collected at 6-14 and 15-23 weeks of gestation. This study was conducted with 135 singleton pregnancies including $17 \mathrm{GH}$ cases, $34 \mathrm{PE}$ cases, and 84 controls. In addition, maternal blood samples and paired placental samples were collected during the first and third trimester. Placental samples were collected during the first trimester by chorionic villus sampling during conventional prenatal diagnostic procedures and during the third trimester after cesarean section delivery.

$\mathrm{PE}$ was defined as hypertension (systolic blood pressure $\geq 140$ $\mathrm{mm} \mathrm{Hg}$ and/or diastolic blood pressure $\geq 90 \mathrm{~mm} \mathrm{Hg}$, twice, $44 \mathrm{~h}$ apart) and proteinuria ( $\geq 0.3 \mathrm{~g}$ /day urine collection and/or $\geq 1+$ on dipstick testing) after 20 weeks of gestation [23]. GH was defined as de novo hypertension, without proteinuria, arising after 20 weeks of gestation and returning to normal postpartum [23]. Normal pregnancy was defined as term delivery ( $\geq 37$ weeks) without medical or obstetric complications. Data on pregnancy outcomes were collected from maternal and pediatric records. No participants in this study had a history of chronic hypertension, diabetes mellitus, or PE.

\section{Bisulfite Direct Sequencing}

To confirm the methylation patterns of candidate epigenetic markers DSCR3 (cffDNA) and HYP2 (cfDNA), which were reported by previous studies using tiling array [24,25], we analyzed changes in the methylation patterns of the DSCR 3 and HYP2 genes using bisulfite direct sequencing. Genomic DNA was extracted from 6 normal pregnancies and $6 \mathrm{PE}$ pregnancies using 3 pairs of placental tissues and maternal blood cells from the first $(n=3)$ and third trimesters $(\mathrm{n}=3)$ from each group using the QIAamp DNA Mini kit (Qiagen, Hilden, Germany). Extracted genomic DNA $(1 \mu \mathrm{g})$ was bisulfite converted using an EpiTect Bisulfite Kit (Qiagen) according to the manufacturer's instructions. The bisulfiteconverted DNA was then amplified by PCR. The sequences of PCR primers are presented in online supplementary table S1 (see www. karger.com/doi/10.1159/000444524 for all online suppl. material). 
Table 1. Maternal characteristics and perinatal outcome of the study groups

\begin{tabular}{|c|c|c|c|c|}
\hline Characteristic & $\begin{array}{l}\text { Controls } \\
(\mathrm{n}=84)\end{array}$ & $\begin{array}{l}\mathrm{GH} \\
(\mathrm{n}=17)\end{array}$ & $\begin{array}{l}\mathrm{PE} \\
(\mathrm{n}=34)\end{array}$ & $\begin{array}{l}\text { HDP } \\
(n=51)\end{array}$ \\
\hline Maternal age, years & $33.0(31.0-35.3)$ & $33.0(32.5-36.5)$ & $34.1(32.7-36.0)$ & $34.0(32.8-36.0)$ \\
\hline Nulliparity & $46(54.8)$ & $11(64.6)$ & $25(73.5)$ & $36(70.6)$ \\
\hline Maximum SBP, mm Hg & $107.5(101.0-116.0)$ & $159.0(151.8-164.5)^{*}$ & $149.5(141.9-158.1)^{*}$ & $151.0(147.5-159.3)^{*}$ \\
\hline Birthweight, $g$ & $3,200(3,027-3,496)$ & $3,010(2,791-3,110)^{*}$ & $2,920(2,390-3,193)^{*}$ & $2,920(2,710-3,145)^{*}$ \\
\hline Sex ratio of fetus (male:female) & $43: 41$ & $6: 11$ & $16: 18$ & $22: 29$ \\
\hline GA at delivery, weeks & $39.5(39.0-40.2)$ & $38.6(38.2-39.5)^{*}$ & $38.3(36.6-39.2)^{*}$ & $38.3(37.3-39.4)^{*}$ \\
\hline Cesarean delivery & $32(38.1)$ & $7(41.2)$ & $21(61.8)^{*}$ & $29(56.9)^{*}$ \\
\hline Alcohol intake & $30(35.7)$ & $2(11.8)$ & $9(26.5)$ & $11(21.6)$ \\
\hline Smoking & $0(0.0)$ & $0(0.0)$ & $0(0.0)$ & $0(0.0)$ \\
\hline $\mathrm{uE}_{3} \mathrm{MoM}$ & $1.2(0.9-1.3)$ & $0.9(0.6-1.0)^{*}$ & $1.2(0.8-1.5)$ & $1.0(0.8-1.3)$ \\
\hline InhA MoM & $0.9(0.7-1.2)$ & $1.9(1.2-2.0)^{*}$ & $0.9(0.7-1.7)$ & $1.2(0.9-2.0)^{*}$ \\
\hline
\end{tabular}

Data are expressed as median (interquartile range) or $\mathrm{n}(\%) . \mathrm{SBP}=$ Systolic blood pressure; $\mathrm{DBP}=$ diastolic blood pressure; $\mathrm{GA}=$ gestational age. * Statistical significance between each patient group and controls.

After PCR amplification, products were purified using a PCR purification kit (Bioneer, Daejeon, Korea) and sequenced using a PRISM BigDye Terminator Cycle Sequencing Kit (Applied Biosystems, Foster City, Calif., USA) according to the manufacturer's instructions. Sequencing products were analyzed using an ABI 3130XL Genetic Analyzer (Applied Biosystems), and electropherogram traces were interpreted with DNA sequencing analysis software version 5.3 (Applied Biosystems). All CpG sites in DSCR3 were completely unmethylated in the maternal blood cells (online suppl. fig. S1A). Methylated CpG sites in DSCR3 were only detected in placental tissues (online suppl. fig. S1A). All CpG sites in HYP2 were completely methylated in both the maternal blood cells and placental tissues (online suppl. fig. S1B). There was no significant difference in the methylation pattern of the first- and third-trimester placental tissues between the $\mathrm{PE}$ and control groups.

\section{DNA Extraction and Enrichment of Methylated DNA}

Maternal blood samples $(10 \mathrm{ml})$ were collected in EDTA tubes and were immediately centrifuged at $1,600 \mathrm{~g}$ for $10 \mathrm{~min}$ at $4^{\circ} \mathrm{C}$. The supernatant plasma was re-centrifuged at $16,000 \mathrm{~g}$ for $10 \mathrm{~min}$ at $4^{\circ} \mathrm{C}$ and aliquoted into $1 \mathrm{ml}$ for circulating cell-free DNA extraction. The peripheral blood cell portion was re-centrifuged at $2,500 \mathrm{~g}$ for $10 \mathrm{~min}$ to remove any residual plasma. Circulating cellfree DNA was extracted from $1 \mathrm{ml}$ of maternal plasma using the QIAamp DSP Virus Kit (Qiagen). The MethylMiner ${ }^{\mathrm{TM}}$ methylated DNA enrichment kit (Invitrogen, Carlsbad, Calif., USA) by methyl-CpG binding domain (MBD) biotin protein was used to isolate methylated DNA from circulating DNA that was extracted from maternal plasma. Finally, the isolated methylated DNA was con- centrated using a DNA concentrator (Zymo Research Corp., Irvine, Calif., USA) and then eluted in a final volume of $30 \mu \mathrm{l}$. Validation was performed using the control DNA (methylated DNA and unmethylated DNA) included in the kit according to the manufacturer's recommendations.

\section{Real-Time Quantitative PCR}

We analyzed the levels of maternal plasma cffDNA and cfDNA using real-time quantitative PCR in all samples without failure of MBD capture. Quantifications of the DSCR3 and RASSF1A genes as cffDNA markers were performed in duplex reactions with the HYP2 gene as a cfDNA marker. Real-time quantitative PCR amplification was performed using the ABI 7500 Real Time System (Applied Biosystems, Branchburg, N.J., USA). The duplex reactions were set up in a volume of $20 \mu$ l, using $5 \mu \mathrm{l} 4 \mathrm{X}$ NEXpro $^{\mathrm{TM}} \mathrm{Dia}$ PCR Master Mix (Geneslabs, Seongnam, Korea) and $6 \mu$ of the methylated plasma DNA captured by MBD. Primers and probes were used at final concentrations of $250 \mathrm{nM}$ each for DSCR3, RASSF1A, and HYP2. Sequences of primers, probes, and amplicons are shown in online supplementary table $S 1$. A standard curve using serial dilutions of single-stranded synthetic DNA oligonucleotides specific to the DSCR3, RASSF1A, and HYP2 amplicons (Bioneer) was employed. Each standard was amplified in triplicate and included on every PCR plate. All samples were amplified in triplicate and the final data reflected the average of the results.

\section{Statistical Analysis}

Comparisons between outcome groups were done by the $\chi^{2}$ test or Fisher's exact test for categorical variables and by the MannWhitney $\mathrm{U}$ test for continuous variables, both with post hoc Bon- 
Table 2. Comparison of levels and MoM values of DSCR3, RASSF1A, and HYP2 in the first and second trimesters in the study groups

\begin{tabular}{|c|c|c|c|c|c|c|}
\hline \multirow[t]{2}{*}{ Study group } & \multicolumn{2}{|l|}{ DSCR3 } & \multicolumn{2}{|l|}{ RASSF1A } & \multicolumn{2}{|l|}{ HYP2 } \\
\hline & copies/ml & MoM & copies/ml & MoM & copies/ml & MoM \\
\hline \multicolumn{7}{|l|}{ Controls } \\
\hline First trimester & 890.9 & 1.000 & 445.6 & 0.912 & $5,188.1$ & 0.921 \\
\hline$(n=53)$ & $(538.9-1,530.0)$ & $(0.605-1.717)$ & $(262.9-936.4)$ & $(0.538-1.916)$ & $(2,042.6-7,682.5)$ & $(0.363-1.364)$ \\
\hline Second trimester & $1,779.7$ & 0.860 & $1,333.8$ & 0.999 & $8,505.4$ & 0.888 \\
\hline$(n=31)$ & $(1,443.8-2,590.6)$ & $(0.698-1.252)$ & $(727.9-2,403.3)$ & $(0.545-1.801)$ & $(5,794.7-11,479.2)$ & $(0.605-1.198)$ \\
\hline \multicolumn{7}{|l|}{$\mathrm{GH}$} \\
\hline First trimester & $1,098.3$ & 1.233 & 450.1 & 0.921 & $7,141.3$ & 1.268 \\
\hline$(\mathrm{n}=10)$ & $(561.7-2,073.6)$ & $(0.630-2.327)$ & $(385.1-719.7)$ & $(0.788-1.473)$ & $(5,099.4-16,997.8)$ & $(0.905-3.017)$ \\
\hline Second trimester & $1,692.8$ & 0.818 & $1,013.3$ & 0.759 & $9,016.1$ & 0.941 \\
\hline$(\mathrm{n}=7)$ & $(1,220.7-2,009.1)$ & $(0.590-0.971)$ & $(716.5-1,375.0)$ & $(0.537-1.030)$ & $(8,137.5-9,972.9)$ & $(0.849-1.041)$ \\
\hline \multicolumn{7}{|l|}{$\mathrm{PE}$} \\
\hline First trimester & 939.1 & 1.054 & 668.8 & 1.369 & $7,169.6$ & 1.273 \\
\hline$(\mathrm{n}=14)$ & $(685.5-1,718.2)$ & $(0.769-1.929)$ & $(455.5-961.6)$ & $(0.932-1.968)$ & $(4,895.2-12,384.1)^{*}$ & $(0.869-2.198)^{*}$ \\
\hline Second trimester & $2,594.0$ & 1.254 & $1,652.6$ & 1.238 & $11,262.4$ & 1.175 \\
\hline$(n=20)$ & $(2,113.4-3,001.9)$ & $(1.021-1.451)$ & $(1,067.9-2,314.1)$ & $(0.800-1.734)$ & $(9,416.3-16,781.1)^{*}$ & $(0.983-1.751)^{*}$ \\
\hline \multicolumn{7}{|l|}{$\mathrm{HDP}$} \\
\hline First trimester & 939.1 & 1.054 & 595.2 & 1.218 & $7,169.6$ & 1.273 \\
\hline$(\mathrm{n}=24)$ & $(607.4-1,856.1)$ & $(0.682-2.083)$ & $(400.4-868.1)$ & $(0.819-1.777)$ & $(4,897.0-13,896.0)^{*}$ & $(0.869-2.467)^{*}$ \\
\hline Second trimester & $2,421.4$ & 1.170 & $1,473.2$ & 1.104 & $10,848.9$ & 1.132 \\
\hline$(\mathrm{n}=27)$ & $(1706.9-2,860.7)$ & $(0.825-1.383)$ & $(809.1-1,921.7)$ & $(0.606-1.440)$ & $(8,653.2-14,889.5)^{*}$ & $(0.903-1.554)^{*}$ \\
\hline
\end{tabular}

Data are expressed as median (interquartile range). * Statistical significance between each patient group and controls.

ferroni correction. The results of cfDNA and cffDNA for all subjects were converted to MoM values. Receiver operating characteristic (ROC) curves were generated from the logistic regression after adjustment for BMI. The performance for screening by DSCR3, RASSF1A, HYP2, and PAPP-A MoM values, individually and in various combinations, was determined by areas under the ROC curve (AUC) and detection rate at a fixed false-positive rate. For all statistical analyses, $\mathrm{p}$ value $<0.05$ was considered statistically significant. Statistical analysis was performed using the Statistical Package for Social Sciences version 12.0 (SPSS Inc., Chicago, Ill., USA).

\section{Results}

\section{Clinical Characteristics of the Study Population}

The clinical characteristics of the study groups are shown in table 1 . There were no statistical differences in maternal age, nulliparity, fetal sex ratio, alcohol intake, or smoking in the patient groups compared with the control group. The patient groups had significantly higher prepregnancy BMI than the control group. As expected, patient groups had significantly higher systolic and diastolic blood pressures than the controls. Gestational age at delivery and birth weight were significantly lower in the patient groups compared with the controls. Delivery by cesarean section was higher in the PE and HDP groups than in the controls.

\section{Levels of Prenatal Screening Biochemical Markers in} the First and Second Trimesters

Table 1 shows the distribution of median MoM values of all biochemical markers in the control and patient groups. The $\mathrm{GH}$ group had significantly lower $\mathrm{uE}_{3}$ and significantly higher InhA than the controls. The PE group had significantly lower PAPP-A than the controls. The HDP group had significantly lower PAPP-A and significantly higher InhA than the controls.

\section{Levels of cffDNA and cfDNA in Maternal Plasma in} the First and Second Trimesters

All data are presented as median levels (copies/ml) and MoM values in table 2. At 6-14 weeks, the median levels and MoM values of HYP 2 in both the PE and HDP groups were significantly different from the control group. At 15-23 weeks, the median levels and MoM values of HYP2 were significantly higher in both the PE and HDP groups than in the controls. In the GH group, compared with the controls, these significant alterations of HYP2 were not 
Table 3. Predictive values for PE and HDP of single marker and various combined markers in the first trimester

\begin{tabular}{|c|c|c|c|c|}
\hline & \multirow[t]{2}{*}{ AUC (95\% CI) } & \multirow[t]{2}{*}{$\mathrm{p}$ value } & \multicolumn{2}{|c|}{ Detection rate, $\%$} \\
\hline & & & $5 \% \mathrm{FPR}$ & $10 \% \mathrm{FPR}$ \\
\hline \multicolumn{5}{|l|}{ PE } \\
\hline DSCR3 & $0.563(0.435-0.685)$ & 0.4499 & 16.2 & 23.0 \\
\hline RASSF1A & $0.617(0.489-0.734)$ & 0.1358 & 15.0 & 30.1 \\
\hline HYP2 & $0.682(0.557-0.790)$ & 0.0268 & 32.8 & 45.2 \\
\hline PAPP-A & $0.697(0.591-0.789)$ & 0.0005 & 23.2 & 33.9 \\
\hline DSCR3 and HYP2 & $0.687(0.561-0.795)$ & 0.0205 & 36.0 & 45.0 \\
\hline RASSF1A and HYP2 & $0.680(0.554-0.789)$ & 0.0289 & 27.0 & 45.0 \\
\hline$D S C R 3$ and RASSF1A & $0.630(0.501-0.747)$ & 0.0870 & 15.1 & 22.6 \\
\hline DSCR3, RASSF1A and HYP2 & $0.707(0.581-0.814)$ & 0.0076 & 26.9 & 44.8 \\
\hline DSCR3 and PAPP-A & $0.814(0.670-0.914)$ & 0.0001 & 44.7 & 65.1 \\
\hline RASSF1A and PAPP-A & $0.803(0.659-0.905)$ & 0.0001 & 42.8 & 62.3 \\
\hline HYP2 and PAPP-A & $0.820(0.677-0.918)$ & $<0.0001$ & 47.2 & 65.4 \\
\hline DSCR3, HYP2 and PAPP-A & $0.832(0.689-0.928)$ & $<0.0001$ & 54.0 & 67.0 \\
\hline RASSF1A, HYP2 and PAPP-A & $0.823(0.680-0.920)$ & $<0.0001$ & 47.0 & 65.3 \\
\hline DSCR3, RASSF1A and PAPP-A & $0.820(0.677-0.918)$ & 0.0001 & 44.5 & 64.2 \\
\hline DSCR3, RASSF1A, HYP2 and PAPP-A & $0.824(0.679-0.922)$ & $<0.0001$ & 53.6 & 66.8 \\
\hline \multicolumn{5}{|l|}{ HDP } \\
\hline DSCR3 & $0.561(0.442-0.675)$ & 0.3945 & 19.6 & 23.5 \\
\hline RASSF1A & $0.617(0.489-0.734)$ & 0.1358 & 15.0 & 30.1 \\
\hline HYP2 & $0.675(0.559-0.778)$ & 0.0103 & 25.8 & 36.3 \\
\hline PAPP-A & $0.664(0.564-0.753)$ & 0.0024 & 17.0 & 28.9 \\
\hline DSCR 3 and HYP2 & $0.684(0.568-0.786)$ & 0.0061 & 34.0 & 42.4 \\
\hline RASSF1A and HYP2 & $0.682(0.565-0.784)$ & 0.0090 & 34.0 & 42.3 \\
\hline DSCR3 and RASSF1A & $0.578(0.458-0.691)$ & 0.2961 & 19.5 & 23.5 \\
\hline DSCR3, RASSF1A and HYP2 & $0.683(0.565-0.786)$ & 0.0084 & 38.2 & 42.3 \\
\hline DSCR3 and PAPP-A & $0.735(0.591-0.850)$ & 0.0060 & 34.0 & 40.7 \\
\hline RASSF1A and PAPP-A & $0.730(0.587-0.844)$ & 0.0058 & 39.2 & 39.3 \\
\hline HYP2 and PAPP-A & $0.739(0.596-0.853)$ & 0.0048 & 43.5 & 50.8 \\
\hline DSCR3, HYP2 and PAPP-A & $0.751(0.607-0.863)$ & 0.0018 & 47.0 & 58.0 \\
\hline RASSF1A, HYP2 and PAPP-A & $0.741(0.598-0.854)$ & 0.0041 & 40.7 & 49.8 \\
\hline DSCR3, RASSF1A and PAPP-A & $0.737(0.593-0.851)$ & 0.0041 & 40.6 & 47.3 \\
\hline DSCR3, RASSF1A, HYP2 and PAPP-A & $0.743(0.598-0.857)$ & 0.0050 & 46.8 & 50.9 \\
\hline
\end{tabular}

observed in their median levels and MoM values. In addition, there were no significant differences between patient groups and controls in the other epigenetic markers, DSCR 3 and RASSF $1 A$.

\section{Evaluation of the Predictive Values of Single and Combined Markers}

The AUC and detection rate at fixed 5 and 10\% falsepositive rates for the single marker and various combinations at 6-14 weeks are presented in table 3. The combination of the first-trimester DSCR3, HYP2, and PAPP-A MoM values for PE and HDP was the best predictive model with an AUC of 0.832 (95\% CI 0.689-0.928) and
0.751 (95\% CI 0.607-0.863), respectively. Using the best model, screening at fixed 5 and $10 \%$ false-positive rates, the detection rates of PE were 54.0 and $67.0 \%$, respectively. Using the best model, screening at fixed 5 and $10 \%$ false-positive rates, the detection rates of HDP were 47.0 and $58.0 \%$, respectively.

\section{Discussion}

HYP2, located on chromosome 13, is hypermethylated in the placenta as well as in maternal blood cells [25]; based on this report, we determined HYP2 as a hyper- 
methylated total cfDNA marker. However, HYP2 has not been applied and validated for clinical usefulness in adverse pregnancy outcomes. This study has first established a new approach of HYP2 as a total cfDNA epigenetic marker by quantitative analysis of HYP2 level in maternal plasma of normal pregnancies and pregnancies with hypertensive disorder.

We found that median levels of total cfDNA (HYP2 gene) were significantly increased at 6-14 and 15-23 weeks' gestation in PE and HDP. Moreover, the MoM values of total cfDNA in PE and HDP were significantly different from those in the controls. Our findings are consistent with previous reports that cfDNA in maternal plasma was significantly elevated in patients with PE compared with controls [10, 11, 15, 26, 27]. Recently, in the early PE group, compared with the control group, there was a significant increase in the median total cfDNA at 11-13 weeks but the MoM values were not significantly different between the two groups [28]. It is possible that increased release of cfDNA from the abnormal placenta and reduced cfDNA clearance due to inflammation and impaired liver and kidney function are responsible for elevated cfDNA levels $[29,30]$. Maternal DNA, which constitutes the majority of cfDNA, may originate from activated leukocytes that are present in increased numbers in $\mathrm{PE}$, and thus might reflect the generalized maternal inflammation state [31]. Plasma cfDNA levels were significantly higher in patients with HELLP syndrome than in patients with PE without HELLP syndrome [32]. HELLP syndrome is characterized by extensive tissue damage (hepatocellular necrosis and hemolysis), which supports the hypothesis that cellular necrosis might be responsible for increased cfDNA levels in the maternal circulation, at least in PE. However, more detailed studies will be necessary to elucidate the underlying pathophysiologic mechanisms.

Several studies have reported that plasma or serum levels of cffDNA are higher in women with established PE than in normotensive controls. Cotter et al. [33] described this increase at a mean gestation of 16 weeks, and Papantoniou et al. [15] reported differences in the amount of cffDNA at 11-13 weeks in patients who subsequently developed PE. Other studies, however, do not share this observation and present contradictory findings. Crowley et al. [34] did not find increased cffDNA levels before 20 weeks of gestation, and Bauer et al.'s results were inconclusive [35]. Stein et al. [36] also reported no alterations of cffDNA levels in the second trimester in pregnancies with $\mathrm{PE}$. In the present study, the median levels and MoM values of cffDNA (DSCR3 and RASSF1A genes) at 6-14 and 15-23 weeks were not significantly different between the
$\mathrm{PE}$ and control groups. These contradictory findings may be attributed to the use of different genes and methodologies for the quantitation of cffDNA and the selection of different gestational ages of maternal sampling points.

$\mathrm{GH}$ is differentiated from PE by the presence of proteinuria. Proteinuria is a consequence of abnormal transglomerular passage of proteins due to increased permeability of the glomerular basement membrane and impaired reabsorption by the epithelial cells of the proximal tubules in the kidney. Our study revealed that levels of cffDNA and cfDNA were not significantly different in the $\mathrm{GH}$ group. $\mathrm{GH}$ might not be associated with impaired clearance of cffDNA and cfDNA due to aberrant transrenal excretion of circulating cffDNA and cfDNA because patients with GH do not have protein in the urine or other signs of organ damage. This result could also be explained by findings from other investigators comparing placental pathology in pregnancies with GH and PE [37, 38]. They suggested that placental ischemia is confined to $\mathrm{PE}$. Endothelial dysfunction and imbalance between proand antiangiogenic factors are specific to $\mathrm{PE}$, but not $\mathrm{GH}$ [39]. Therefore, it has been suggested that $\mathrm{GH}$ and $\mathrm{PE}$ are separate disease entities with different pathophysiology and mechanism.

PAPP-A, a protease for insulin-like growth factor (IGF) binding protein-4 [40], is produced by developing trophoblast cells and is used for aneuploidy screening in many countries. If the level of PAPP-A is insufficient to successfully cleave IGF binding protein- 4 , it remains in its bound, inactive form. Therefore, less free IGF may lead to diminished fetal and placental growth [41]. PAPP-A is established as a biomarker for the early prediction of $\mathrm{PE}$ and is recommended by the Fetal Medicine Foundation [42]. Despite a significant association between low PAPPA levels and adverse pregnancy outcomes, PAPP-A is a poor single screening marker for PE [43]. However, when combined with other screening markers, the test performance of PAPP-A improves considerably [43]. Spencer et al. [44] reported that combining first-trimester serum PAPP-A with uterine artery mean pulsatility improved PE prediction. Akolekar et al. [42] developed an effective first-trimester screening model for PE using PAPPA, placental growth factor MoM values, uterine artery pulsatility index, and mean arterial pressure. In this study, the combination of the first-trimester cffDNA and cfDNA epigenetic markers with PAPP-A improved the predictive value for PE and HDP.

In conclusion, this study shows that the combination of the first-trimester DSCR3, HYP2, and PAPP-A MoM values is the best predictor for early detection of $\mathrm{PE}$. 
Therefore, this combination could be useful for predicting PE. However, this study is limited by its relatively small sample size and the inclusion of only Korean women. Therefore, external validation of this combination in a larger-scale study in different ethnic populations is needed to confirm that it is a powerful tool for the early prediction of women at risk for developing PE.

\section{Acknowledgements}

This study was supported by a grant of the Korean Health Technology R\&D Project, Ministry of Health and Welfare, Republic of Korea (HI13C1934).

\section{References}

1 Sibai BM: Diagnosis and management of gestational hypertension and preeclampsia. Obstet Gynecol 2003;102:181-192.

$>2$ Vatten LJ, Skjaerven R: Is pre-eclampsia more than one disease? BJOG 2004;111:298-302.

3 Hauth JC, Ewell MG, Levine RJ, Esterlitz JR, Sibai B, Curet LB, Catalano PM, Morris CD: Pregnancy outcomes in healthy nulliparas who developed hypertension. Calcium for Preeclampsia Prevention Study Group. Obstet Gynecol 2000;95:24-28.

$\checkmark 4$ Ness RB, Roberts JM: Heterogeneous causes constituting the single syndrome of preeclampsia: a hypothesis and its implications. Am J Obstet Gynecol 1996;175:1365-1370.

$\checkmark 5$ Redman CW, Sargent IL: Placental debris, oxidative stress and pre-eclampsia. Placenta 2000;21:597-602.

6 Rusterholz C, Messerli M, Hoesli I, Hahn S: Placental microparticles, DNA, and RNA in preeclampsia. Hypertens Pregnancy 2011;30: 364-375.

7 Lo YM, Corbetta N, Chamberlain PF, Rai V, Sargent IL, Redman CW, Wainscoat JS: Presence of fetal DNA in maternal plasma and serum. Lancet 1997;350:485-487.

$>8$ Lo YM, Leung TN, Tein MS, Sargent IL, Zhang J, Lau TK, Haines CJ, Redman CW: Quantitative abnormalities of fetal DNA in maternal serum in preeclampsia. Clin Chem 1999;45:184-188.

$>9$ Leung TN, Zhang J, Lau TK, Chan LY, Lo YM: Increased maternal plasma fetal DNA concentrations in women who eventually develop preeclampsia. Clin Chem 2001;47:137-139.

10 Zhong XY, Holzgreve W, Hahn S: The levels of circulatory cell free fetal DNA in maternal plasma are elevated prior to the onset of preeclampsia. Hypertens Pregnancy 2002;21:7783.

$>11$ Farina A, Sekizawa A, Iwasaki M, Matsuoka R, Ichizuka K, Okai T: Total cell-free DNA (beta-globin gene) distribution in maternal plasma at the second trimester: a new prospective for preeclampsia screening. Prenat Diagn 2004;24:722-726.

12 Farina A, Sekizawa A, Sugito Y, Iwasaki M, Jimbo M, Saito H, Okai T: Fetal DNA in maternal plasma as a screening variable for pre- eclampsia. A preliminary nonparametric analysis of detection rate in low-risk nonsymptomatic patients. Prenat Diagn 2004;24: 83-86.

13 Chan KC, Ding C, Gerovassili A, Yeung SW, Chiu RW, Leung TN, Lau TK, Chim SS, Chung GT, Nicolaides KH, Lo YM: Hypermethylated RASSF1A in maternal plasma: a universal fetal DNA marker that improves the reliability of noninvasive prenatal diagnosis. Clin Chem 2006;52:2211-2218.

14 Chiu RW, Chim SS, Wong IH, Wong CS, Lee WS, To KF, Tong JH, Yuen RK, Shum AS, Chan JK, Chan LY, Yuen JW, Tong YK, Weier JF, Ferlatte C, Leung TN, Lau TK, Lo KW, Lo YM: Hypermethylation of RASSF1A in human and rhesus placentas. Am J Pathol 2007;170:941-950.

15 Papantoniou N, Bagiokos V, Agiannitopoulos K, Kolialexi A, Destouni A, Tounta G, Kanavakis E, Antsaklis A, Mavrou A: RASSF1A in maternal plasma as a molecular marker of preeclampsia. Prenat Diagn 2013;33: 682-687.

16 Malone FD, Canick JA, Ball RH, Nyberg DA, Comstock CH, Bukowski R, Berkowitz RL, Gross SJ, Dugoff L, Craigo SD, Timor-Tritsch IE, Carr SR, Wolfe HM, Dukes K, Bianchi DW, Rudnicka AR, Hackshaw AK, LambertMesserlian G, Wald NJ, D'Alton ME: Firsttrimester or second-trimester screening, or both, for Down's syndrome. N Engl J Med 2005;353:2001-2011.

17 Wald NJ, Kennard A, Hackshaw A, McGuire A: Antenatal screening for Down's syndrome. J Med Screen 1997;4:181-246.

18 Haddow JE, Palomaki GE, Knight GJ, Williams J, Miller WA, Johnson A: Screening of maternal serum for fetal Down's syndrome in the first trimester. N Engl J Med 1998;338: 955-961.

19 Spencer K, Cowans NJ, Nicolaides KH: Low levels of maternal serum PAPP-A in the first trimester and the risk of pre-eclampsia. Prenat Diagn 2008;28:7-10.

20 Goetzinger KR, Singla A, Gerkowicz S, Dicke JM, Gray DL, Odibo AO: Predicting the risk of pre-eclampsia between 11 and 13 weeks' gestation by combining maternal characteris- tics and serum analytes, PAPP-A and free $\beta$-hCG. Prenat Diagn 2010;30:1138-1142.

21 Aquilina J, Maplethorpe R, Ellis P, Harrington $\mathrm{K}$ : Correlation between second trimester maternal serum inhibin-A and human chorionic gonadotrophin for the prediction of pre-eclampsia. Placenta 2000;21: 487-492.

22 Sibai BM, Koch MA, Freire S, Pinto e Silva JL, Rudge MV, Martins-Costa S, Bartz J, de Barros Santos C, Cecatti JG, Costa R, Ramos JG, Spinnato JA 2nd: Serum inhibin A and angiogenic factor levels in pregnancies with previous preeclampsia and/or chronic hypertension: are they useful markers for prediction of subsequent preeclampsia? Am J Obstet Gynecol 2008;199:268.e1-e9.

23 ACOG practice bulletin: Diagnosis and management of preeclampsia and eclampsia. Int J Gynaecol Obstet 2002;77:67-75

24 Kim HJ, Kim SY, Lim JH, Kwak DW, Park SY, Ryu HM: Quantification and application of potential epigenetic markers in maternal plasma of pregnancies with hypertensive disorders. Int J Mol Sci 2015;16:29875-29888.

25 Papageorgiou EA, Fiegler H, Rakyan V, Beck S, Hulten M, Lamnissou K, Carter NP, Patsalis PC: Sites of differential DNA methylation between placenta and peripheral blood: molecular markers for noninvasive prenatal diagnosis of aneuploidies. Am J Pathol 2009; 174:1609-1618.

26 Zhong XY, Laivuori H, Livingston JC, Ylikorkala O, Sibai BM, Holzgreve W, Hahn $\mathrm{S}$ : Elevation of both maternal and fetal extracellular circulating deoxyribonucleic acid concentrations in the plasma of pregnant women with preeclampsia. Am J Obstet Gynecol 2001;184:414-419.

27 Kim MJ, Kim SY, Park SY, Ahn HK, Chung JH, Ryu HM: Association of fetal-derived hypermethylated RASSF1A concentration in placenta-mediated pregnancy complications. Placenta 2013;34:57-61.

28 Rolnik DL, O'Gorman N, Fiolna M, van den Boom D, Nicolaides KH, Poon LC: Maternal plasma cell-free DNA in the prediction of preeclampsia. Ultrasound Obstet Gynecol 2015; 45:106-111. 
29 Levine RJ, Qian C, Leshane ES, Yu KF, England LJ, Schisterman EF, Wataganara T, Romero R, Bianchi DW: Two-stage elevation of cell-free fetal DNA in maternal sera before onset of preeclampsia. Am J Obstet Gynecol 2004;190:707-713.

- 30 Wataganara T, Bianchi DW: Fetal cell-free nucleic acids in the maternal circulation: new clinical applications. Ann N Y Acad Sci 2004; 1022:90-99.

-31 Gupta A, Hasler P, Gebhardt S, Holzgreve W, Hahn S: Occurrence of neutrophil extracellular DNA traps (NETs) in pre-eclampsia: a link with elevated levels of cell-free DNA? Ann N Y Acad Sci 2006;1075:118-122.

32 DiFederico E, Genbacev O, Fisher SJ: Preeclampsia is associated with widespread apoptosis of placental cytotrophoblasts within the uterine wall. Am J Pathol 1999;155: 293-301.

33 Cotter AM, Martin CM, O'Leary JJ, Daly SF: Increased fetal DNA in the maternal circulation in early pregnancy is associated with an increased risk of preeclampsia. Am J Obstet Gynecol 2004;191:515-520.
34 Crowley A, Martin C, Fitzpatrick P, Sheils O, O’Herlihy C, O'Leary JJ, Byrne BM: Free fetal DNA is not increased before 20 weeks in intrauterine growth restriction or pre-eclampsia. Prenat Diagn 2007;27:174-179.

35 Bauer M, Hutterer G, Eder M, Majer S, Leshane E, Johnson KL, Peter I, Bianchi DW, Pertl B: A prospective analysis of cell-free fetal DNA concentration in maternal plasma as an indicator for adverse pregnancy outcome. Prenat Diagn 2006;26:831-836.

36 Stein W, Müller S, Gutensohn K, Emons G, Legler T: Cell-free fetal DNA and adverse outcome in low risk pregnancies. Eur J Obstet Gynecol Reprod Biol 2013;166:10-13.

37 Corrêa RR, Gilio DB, Cavellani CL, Paschoini MC, Oliveira FA, Peres LC, Reis MA, Teixeira VP, Castro EC: Placental morphometrical and histopathology changes in the different clinical presentations of hypertensive syndromes in pregnancy. Arch Gynecol Obstet 2008;277:201-206.

38 Maloney KF, Heller D, Baergen RN: Types of maternal hypertensive disease and their association with pathologic lesions and clinical factors. Fetal Pediatr Pathol 2012;31:319-323.

39 Noori M, Donald AE, Angelakopoulou A, Hingorani AD, Williams DJ: Prospective study of placental angiogenic factors and maternal vascular function before and after preeclampsia and gestational hypertension. Circulation 2010;122:478-487.
0 Lawrence JB, Oxvig C, Overgaard MT, Sottrup-Jensen L, Gleich GJ, Hays LG, Yates JR 3rd, Conover CA: The insulin-like growth factor (IGF)-dependent IGF binding protein- 4 protease secreted by human fibroblasts is pregnancy-associated plasma protein-A. Proc Natl Acad Sci USA 1999;96:3149-3153.

41 Peterson SE, Simhan HN: First-trimester pregnancy-associated plasma protein $\mathrm{A}$ and subsequent abnormalities of fetal growth. Am J Obstet Gynecol 2008;198:e43-e45.

42 Akolekar R, Syngelaki A, Poon L, Wright D, Nicolaides KH: Competing risks model in early screening for preeclampsia by biophysical and biochemical markers. Fetal Diagn Ther 2013;33:8-15.

43 Anderson UD, Olsson MG, Kristensen KH, Åkerström B, Hansson SR: Review: Biochemical markers to predict preeclampsia. Placenta 2012;26:42-47.

44 Spencer K, Yu CK, Cowans NJ, Otigbah C, Nicolaides KH: Prediction of pregnancy complications by first-trimester maternal serum PAPP-A and free beta-hCG and with secondtrimester uterine artery Doppler. Prenat Diagn 2005;25:949-953. 